Article

\title{
Forecasting the Impact of Gross Domestic Product (GDP) on International Tourist Arrivals to Langkawi, Malaysia: A PostCOVID-19 Future
}

\author{
Hasrina Mustafa ${ }^{1, *(\mathbb{D})}$, Fahri Ahmed ${ }^{1}\left(\mathbb{D}\right.$, Waffa Wahida Zainol ${ }^{2}$ and Azlizan Mat Enh ${ }^{3}(\mathbb{D}$ \\ 1 School of Communication, Universiti Sains Malaysia, Penang 11800, Malaysia; fahriahmd7@gmail.com \\ 2 Langkawi Development Authority, LADA Complex, Jalan Persiaran Putra 07000, Malaysia; \\ waffa@lada.gov.my \\ 3 Research Center for History, Politics and International Affairs, Faculty of Social Sciences and Humanities, \\ Universiti Kebangsaan Malaysia, Bangi 43600, Malaysia; azlizan@ukm.edu.my \\ * Correspondence: hasrina@usm.my; Tel.: +60-326810091
}

Citation: Mustafa, H.; Ahmed, F.; Zainol, W.W.; Mat Enh, A. Forecasting the Impact of Gross Domestic Product (GDP) on International Tourist Arrivals to Langkawi, Malaysia: A PostCOVID-19 Future. Sustainability 2021, 13, 13372. https://doi.org/ $10.3390 /$ su132313372

Academic Editor: Kisang Ryu

Received: 9 September 2021

Accepted: 18 November 2021

Published: 2 December 2021

Publisher's Note: MDPI stays neutral with regard to jurisdictional claims in published maps and institutional affiliations.

Copyright: (c) 2021 by the authors. Licensee MDPI, Basel, Switzerland. This article is an open access article distributed under the terms and conditions of the Creative Commons Attribution (CC BY) license (https:/ / creativecommons.org/licenses/by/ $4.0 /)$.

\begin{abstract}
This research first aims to forecast tourist arrivals to Langkawi, Malaysia from its top three source markets, namely, China, Saudi Arabia, and the United Kingdom, between 2020 and 2022. Using the annual gross domestic product (GDP) growth of those three countries, the study seeks to investigate the impact of GDP on tourist arrivals from these countries to Langkawi in the context of post-COVID-19 scenarios. The study uses expert modelers, namely, ARIMA models and Holt's linear models, to find the best fit model. Then, linear regression analysis was conducted to assess the impact of GDP on tourist arrivals in Langkawi from the said three countries. The results from the Holt linear model predicted a significant increase in the number of tourist arrivals from China and Saudi Arabia from 2020-2022. In contrast, the number of forecasted tourist arrivals from the United Kingdom would be on a decreasing trend from 2020-2022. It is also predicted that GDP growth will influence the tourist arrival trends from China and Saudi Arabia, but not for UK tourists. In other words, a speedy rate of recovery in the number of tourists from the UK to Langkawi is forecasted for once international travel restrictions are lifted, as the world eases into the post-pandemic period.
\end{abstract}

Keywords: forecasting model; Langkawi; tourist arrival; COVID-19; gross domestic product; Malaysia

\section{Introduction}

Tourism is a very important industry in Malaysia that has a far-reaching impact on the country's economic, social, and cultural development. It is the third major foreign exchange earner, after manufacturing and palm oil. It plays a significant role in the Malaysian economy through employment generation and the expansion of various related industries, such as food, accommodation, and transportation. Culturally, the tourism industry leads to the enrichment of and a greater appreciation for local cultures, traditional dances, costumes, handicrafts, and folk arts, which, in turn, lead to the growth of local trades and businesses related to cultural products.

The rapid growth of the tourism industry in Malaysia can be seen from the steady increase in tourist arrivals and tourist receipts. Recent statistics from Tourism Malaysia recorded a significant increase in tourist arrivals, from 25.72 million in 2015 to 26.10 million in 2019. A positive trend can be seen from tourist receipts, which increased from USD 16.5 billion in 2015 to USD 20.6 billion in 2019 [1]. In late 2019, a year-long Visit Malaysia Year 2020 program was strategically planned by the Ministry of Tourism, Arts and Culture Malaysia to bring in an estimated 30 million tourists, with a total estimated receipt of USD 23.9 billion. However, the grand national plan by the ministry to launch the campaign has been called off, due to the COVID-19 pandemic [2].

Langkawi is the top tourism island destination in Malaysia. Langkawi's tourism industry has remained strong and vibrant, as indicated by the steady increase in tourist 
arrivals and receipts for the past five years. Tourism statistics indicate a significant increase in tourist arrivals, from 3.06 million in 2012 to 3.62 million in 2015. Similarly, tourist receipts grew, from USD 641 million in 2012 to USD 962 million in 2015 [3]. Despite the 2014-2015 global and regional economic downturn, the average per diem expenditure in Langkawi has grown from USD 140 in 2013 to USD 152 in 2019. The average per capita expenditure has also increased, from USD 582 in 2013 to USD 742 in 2014, dropping slightly in 2015 to USD 704 in response to the mysterious disappearance of Malaysian Airlines flight MH370, the tragic flight MH17 that was shot down over Ukraine, and other global financial issues, before rising to USD 742 in 2019. The two incidents that occurred within a four-month period severely impacted the tourism industry, resulting in fewer visitors. The average length of stay, which was, earlier, on an upward trend, from 4.20 days in 2013 to 4.31 days in 2014, dropped dramatically in 2015 to 4.02 days in response to these tragedies, before regaining the previous 4.31 days in 2019. Tourists from China, Europe, and the Middle East contributed more than $70 \%$ of the total number of international tourists to Langkawi, at 571,199 in 2019 [3,4].

Despite the sector's proven resilience in moderating the impact of various global incidents in the past, the swift outbreak of COVID-19 jolted the tourism industry of Langkawi. Based on statistics released by the Langkawi Development Authority, the number of visitor arrivals (domestic and international) in 2020 dropped from 3,924,326 in 2019 to only 1,281,107 as of August 2020 [5].

In view of the issues highlighted above, the present study aims to forecast tourist arrivals in Langkawi from its top three source markets, namely, China, Saudi Arabia, and the United Kingdom, for the years 2020-2022. Using the annual gross domestic product (GDP) growth of the three countries, the study seeks to investigate whether the GDP of the three countries would have any significant impact on tourist arrivals to the island.

\section{The Impact of GDP on Tourist Arrivals in the Post-Pandemic Era}

GDP is an important indicator of the economic growth of a country. The term generally refers to all of the output generated within the borders of a country. GDP measures all values of goods and services produced within a country, normally for a year [6]. Past forecasting studies have long documented the positive relationships between the GDP of a country and the number of tourists [7,8]. A good GDP would indicate strong economic growth, good tourism infrastructures, and a safe environment, ensuring a higher tourism growth for a country or destination. However, past studies that measured the impact of the GDP of the tourists' countries of origin on the number of international tourists visiting host countries are severely lacking, except for a few studies by Croes and Vanegas [9], Luzzi and Flückiger [10], and Ghani [11]. In other words, less is known about how the annual GDP growth of the tourists' country of origin predicts the number of inbound tourists to the host country. Would the GDP of the tourists' countries of origin influence the number of inbound tourists to the host destination? The gap is even more evident in the context of a specific destination, such as Langkawi, in the post-pandemic era.

The global pandemic has caused a major collapse of the global economy, typically measured in GDP. The International Monetary Fund (IMF) reported a contraction of $-3.5 \%$ of global economies [12]. In 2020, Malaysia's economy contracted by $-5.6 \%$, compared to $4.4 \%$ in 2019 [13]. The UK recorded a major GDP drop to $-9.8 \%$, compared to $1.4 \%$ in 2019. Saudi Arabia dropped to $-4.1 \%$, compared to $0.3 \%$ in 2019 . China is the only major economy in the world with a positive GDP in 2020 at 2.3\%, compared to 6\% in 2019 [12].

COVID-19 was first detected in Wuhan, China in December 2019. As of late December 2019, the World Health Organization had reported that a number of people in Wuhan were being diagnosed with pneumonia from an unknown source. By 11 January 2020, China reported the first death due to the virus previously known as the novel coronavirus. Since its first detection in December 2019, the virus has spread and infected more than 241.9 million people in more than 218 countries around the world. Officially declared as a global pandemic by the World Health Organization (WHO) on 11 March 2020, the virus 
has killed more than 4.9 million people. The highest number of fatalities was recorded in the United States of America (USA) at 746,000, followed by Brazil at 603,000 and India at 452,000, as of October 2021 [14].

In Malaysia, the pandemic was first detected on 25 January 2020, involving three tourists from China who came to Malaysia via Johor Bharu from Singapore, marking the first wave of infections in Malaysia. The second wave generally began on 27 February 2020, with the number of confirmed cases having increased to more than 1000 in February 2020, leading to the announcement on the Movement Control Order (MCO) on 18 March 2020 to curb its spread. The enforcement of the MCO has led to a total closure of schools, universities, government offices, and private premises; a total ban of any mass gatherings for any religious, social, or cultural purposes; and a complete restriction for all inbound and outbound travel. Following a gradual decrease in the number of confirmed cases in Malaysia, especially in April 2020, the partial lockdown was further relaxed with the introduction of the Recovery Movement Control Order (RCMO) in June 2020. The third wave of the pandemic began after a sharp rise in the number of cases in September 2020, mainly due to the spread of infection from the Sabah prison cluster and Sabah state election held on 26 September 2020. To date, the number of cases in Malaysia has reached more than 2.4 million with 27,993 deaths as of 19 October 2021.

COVID-19 has had an enormous negative impact on the global tourism industry, mainly due to worldwide travel restrictions imposed to curb the spread of the pandemic. It has put a damper on the domestic tourism sector due to the enforcement of various lockdown measures and restrictions of inter-state travel. The United Nations World Tourism Organization (UNTWO) estimated a decline of more than $70 \%$ in international tourist arrivals in 2020, leading to a financial loss of more than USD 935 billion in export revenue. Asian and Pacific regions would be highly impacted with a decrease of more than $82 \%$ in international tourist arrivals, and this would be followed by the Middle East, Africa, and European regions by $73 \%, 69 \%$, and $63 \%$, respectively [15].

At a national level, the losses suffered by Malaysian tourism and culture industries in the first half of 2020 from the COVID-19 pandemic amounted to around USD 10.8 billion. Statistics released by the Department of Statistics Malaysia (DOSM) in April 2020 indicated a significant drop in the employment volume, at one percent, involving more than 14.93 million people over the same period last year. The existing workforce and supply chain of the tourism and hospitality industries are severely affected. Those affected include food and beverage, transportation, the arts, entertainment, and recreation [16].

For Langkawi, the dramatic decline in the overall number of inbound tourists to Malaysia has led to a significant drop in relevant statistical figures. The arrival of international tourists to Langkawi from its source markets has been reduced by more than $66 \%$, compared to the previous year [5]. Tourism and hospitality industries in Langkawi were badly affected, with many hotels and hospitality businesses experiencing losses or shutting down completely.

\section{Forecasting Models Used for Predicting Tourism Arrival}

Tourist arrival trends across different source markets are amongst the most crucial information needed to plan and strategize any tourism agenda. For Langkawi, the information is even more critical in view of the current implementation of various initiatives under the Langkawi Blueprint, which serves as a catalyst towards the vision to list Langkawi among the Global Top 10 Island Destinations and Eco-Tourism Attractions in the world. To accelerate the process, the Blueprint of Langkawi 2016-2020 was launched with five key targets which, amongst others, have the objectives to (a) increase the number of tourists to Langkawi to more than five million and (b) increase tourism revenue from USD 910 million in 2015 to USD 2.15 billion in 2020 [17].

The tourism industry is one of the most vulnerable industries due to the influence of many internal and external factors $[18,19]$. Hence, the accurate forecasting of tourist flow is essential in order to protect and preserve the sustainability and viability of the 
industry. Generally, there are two main forecasting approaches normally used in past studies, namely, time series and econometric models. The time series forecasting model is one of the most popular forecasting approaches among both tourism researchers and practitioners, due to its simplicity with the use of univariate data. The econometrics model, however, is often used for cross-sectional predictions of tourist flow by investigating the effect of independent variables on tourism flow, such as currency exchange rates or the incomes of potential tourists [20].

In previous studies, tourist arrivals have been forecasted using time series modeling techniques, e.g., Integrated Autoregressive Moving Averages (ARIMA), Simple Exponential Smoothing Methods, Holt's linear models, as well as Holt-Winters trends and seasonal models [21]. In past research, it was found that the Moving Average 10 (or MA (10)) model was the best forecasting model based on the smallest root mean square error (RMSE). Other researchers [22] used ARMA and AFRIMA models to conduct the time series modeling of tourist arrivals in Malaysia.

For Langkawi, Abdulsamad Yahya, Ruhaidah Samsudin, and Ani Shabri Ilman [23] used a new forecasting model by combining the Fourier residual modification with an optimized Grey model GM $(1,1)$ to forecast the tourist arrival trends in Langkawi. Using monthly tourist data, empirical results indicate that the proposed forecasting model demonstrates a superior performance compared to other methods, in terms of forecasting accuracy. In contrast, Mansor and Ishak [24] used ARIMA and AFRIMA models to forecast the tourist arrival trend for Langkawi, while Nur Fatihah Fauzi, Nurul Shahiera Ahmad, Nor Hayati Shafii, and Huda Zuhrah Ab. Halim [25] used fuzzy time series and Holt-Winters models for forecasting tourist arrivals in Langkawi. Kedah. Nur Intan Liyana Mohd Azmi [26] also used parameter estimations of the Holt-Winters smoothing method, using genetic algorithms to predict tourist arrivals to Langkawi. Clearly, from the above discussion, ARIMA and Holt-Winters smoothing methods were used to forecast tourist arrivals, especially for Langkawi. The same forecasting models have been used in many other studies related to tourism forecasting [21,27].

Despite their wide usage in the present literature, Abdul Samad Yahya, Ruhaidah Samsudin, and Ani Shabri Ilman addressed some limitations in ARIMA and artificial neural networks, such as that their forecasting performance is often inconsistent and requires complex calculations [23]. However, ARIMA and Holt-Winters smoothing methods have been successfully used in the past for forecasting nonlinear, cyclic, and seasonal data, such as energy consumption and tourist arrivals [28]. Hence, the same methods were considered appropriate for tourist arrival data with trendy and seasonal variation patterns, as is evident in past literatures.

It is important to note that past studies failed to specifically forecast the arrival trends for the source countries and reflect on those findings in the post-pandemic era. In the context of Langkawi as an emerging tourism island, it is important to conduct a forecasting analysis for the top source countries, and not for the overall international tourist arrival, to enable accurate targeting and planning for the specific source countries. To the best of our knowledge, no such studies have been performed before for Langkawi. Hence, the present study aims to fill the void by providing the forecasting trend of tourist arrivals to Langkawi, Malaysia from its top three source markets, namely, China, Saudi Arabia, and the United Kingdom, between 2020 and 2022. Using the annual gross domestic product (GDP) growth of the three countries, the study seeks to investigate whether changes in GDP would have any significant impact on tourist arrivals from these countries to Langkawi in the post-pandemic era.

\section{Materials and Methods}

\subsection{Research Method and Data Set}

The present study used secondary data in achieving the objectives of the study. Currently, the tourist arrival secondary data were collected from Tourism Malaysia and the Langkawi Development Authority, while the annual GDP growth data on China, Saudi 
Arabia, and the United Kingdom were collected from the World Bank data website. The data for this study comprised of secondary yearly data from 2003-2019. For the purpose of this study, the annual GDP growth for the three countries was extracted from the World Bank portal [14]. There are several types of GDP, such as GDP per capita, nominal GDP, and real GDP, but in the present study, data on GDP growth in percentages from 2003-2019 for the three countries was extracted from the website.

In the present study, "tourist" is defined as "a person in the blank space, outside of his/her residence, who spends at least one night in a hotel or other facility for the accommodation of guests, for the determination of resting, recreation, health, study, sports, religious belief, family, public affairs missions, and conferences" [15]. The United Nations World Tourism Organization [15] differentiates the concept of a tourist from a visitor. A visitor is defined as a traveler taking a trip to a main destination outside his/her usual environment, for less than a year, for any main purpose (business, leisure, or other personal purpose) other than to be employed by a resident entity in the country or place visited. A traveler is classified as a tourist if his/her trip includes an overnight stay [29].

\subsection{Data Analysis}

This research studied tourist arrivals from top source markets to Langkawi, namely, China, Saudi Arabia, and the United Kingdom, using both ARIMA models and Holt's linear model. The time series analyses were conducted using the IBM Statistical Package for Social Sciences, version 26, to test the null hypotheses that the tourist arrival data series is stationary from 2003-2019 for China, Saudi Arabia, and the UK. Specifically, the study used an expert modeler to find the best fit model to forecast tourist arrivals from these three countries. Then, the study conducted linear regression analysis to find out whether there is any significant relationship between the annual GDP growth of China, Saudi Arabia, and the United Kingdom, and the number of inbound tourists from those three countries to Langkawi.

The first step of this research was to explore the tourist arrival in Langkawi from China, Saudi Arabia, and the United Kingdom, and then to forecast the estimated tourist arrivals for the years 2020-2022. The second step was conducted to establish a relationship between tourist arrivals from China, Saudi Arabia, and the United Kingdom with the annual GDP growth of their country of origin to study whether changes in GDP would have any significant impact on tourist arrivals from these countries to Langkawi.

It is vital to ascertain the relationship between tourist arrivals from China, Saudi Arabia and the United Kingdom and their annual growth in GDP because the presence of COVID-19 from early 2020 has affected the GDP of many countries. Thus, if there exists any link between tourist arrivals from China, Saudi Arabia, and the United Kingdom and their respective GDP growth, then Langkawi's tourist demand from these countries will be significantly impacted if there are any changes in the GDP of these countries.

To forecast tourist arrivals from China and Saudi Arabia in Langkawi, the best fitted model was found to be the Holt linear model, which is the smoothest form of exponential smoothing. The formula for this model is given below:

$$
S_{t}=\alpha X_{t}+(1-\alpha) S_{t-1}+\alpha\left(X_{t}-S_{t-1}\right)
$$

where $\alpha$ is the smoothing factor at $0 \leq \alpha \leq 1$. This means $S t$ is a simple weighed average of the current observation and the previous smoothed statistic, $S_{t-1}$. This equation generates a smoothed statistic when these two observations are available. This forecasting model was chosen to forecast the data of Chinese and Saudi Arabian tourists because it had the lowest mean absolute error (MAE), root mean square error (RMSE), and mean absolute percentage error (MAPE), as assessed by the expert modeler tool of SPSS.

The ARIMA model is used to forecast time series by separating the signal from the noise so that the signal can be extrapolated into the future to generate forecasts. For stationary time series, the ARIMA forecasting equation, a linear equation in which the predictors are based on the lags of the dependent variable, is used. To forecast the arrival 
of tourists from the UK in Langkawi, the best fitted model was found to be ARIMA $(0,0,0)$. The ARIMA process with zero mean and stationary data $(p, q)$ is defined by sequencing random variables $\left\{X_{t}\right\}$. The equation is:

$$
X_{t}-\varphi_{1} X_{t-1}-\ldots-\varphi p X_{t-p}=Z_{t}+\theta_{1} Z_{t-1}+\ldots+\theta_{q} Z_{t-q},
$$

where $\left\{X_{t}\right\}$ is an ARMA $(p, q)$ with a mean of $\mu$ if $\left\{X_{t-\mu}\right\}$ is an ARMA (p, q) process; or, $\left\{X_{t}\right\}$ is an ARMA $(p, d, q)$ if $d$ is a non-negative integer;

or, $\left\{X_{t}\right\}$ is an ARMA $(p, q)$ if there is $(1-B) d X_{t}$, where $B$ is the usual backward shift operator.

For this research, ARIMA $(0,0,0)$ has been applied to forecast tourist arrivals from the United Kingdom in Langkawi. ARIMA $(0,0,0)$ is a time series model that includes constant white noise in which all the values are the same. This forecasting model was chosen to forecast the data of the United Kingdom's tourists because it had the lowest mean absolute error (MAE), root mean square error (RMSE), and mean absolute percentage error (MAPE), as assessed by the expert modeler tool.

To establish the relationship between the tourist arrivals from China, Saudi Arabia, and the United Kingdom and these countries' GDP growth, linear regression analysis was used. To find whether Chinese tourist arrivals to Langkawi are affected by the annual GDP growth of the origin country, the equation is:

$$
y=\alpha x_{i}+\beta\left(x_{i}\right)
$$

where:

$\mathrm{y}=$ Tourist arrivals from China to Langkawi;

$\mathrm{x}_{\mathrm{i}}=$ Annual GDP growth of China;

$\alpha=\alpha$ is the $y$-intercept or constant in the equation;

and $\beta=\beta$ is the slope of the equation, which is also known as the regression coefficient.

To find whether Saudi Arabian tourist arrivals to Langkawi are affected by the annual GDP growth of the origin country, the equation is:

$$
y=\alpha x_{i i}+\beta\left(x_{i i}\right)
$$

where:

$\mathrm{y}=$ Tourist arrivals from Saudi Arabia to Langkawi;

$\mathrm{x}_{\mathrm{ii}}=$ Annual GDP growth of Saudi Arabia;

$\alpha=\alpha$ is the $y$-intercept or constant in the equation;

and $\beta=\beta$ is the slope of the equation, which is also known as the regression coefficient.

To find whether the United Kingdom's tourist arrivals to Langkawi are affected by the annual GDP growth of the origin country, the equation is:

$$
y=\alpha x_{i i i}+\beta\left(x_{i i i}\right)
$$

where:

$\mathrm{y}=$ Tourist arrivals from UK to Langkawi;

$\mathrm{x}_{\mathrm{iii}}=$ Annual GDP growth of UK;

$\alpha=\alpha$ is the $y$-intercept or constant in the equation;

and $\beta=\beta$ is the slope of the equation, which is also known as the regression coefficient.

\section{Results}

This research is driven by an interest to forecast tourist arrival trends to Langkawi, Malaysia from its top three source markets, namely, China, Saudi Arabia, and the United Kingdom, between 2020 and 2022, and to investigate whether GDP trends have any significant impact on tourist arrivals from these countries in the context of post-COVID-19 scenarios. Table 1 shows the number of tourist arrivals from China, Saudi Arabia, and 
the United Kingdom from 2003-2019. It reflects that China was the top source market to Langkawi, with high growth in recent years, followed by Saudi Arabia and the United Kingdom, as seen in Figure 1 as well.

Table 1. Tourist arrivals to Langkawi from China, Saudi Arabia, and the United Kingdom.

\begin{tabular}{cccc}
\hline Year & China & Saudi Arabia & United Kingdom \\
\hline 2003 & 5340 & 565 & 8720 \\
2004 & 12,753 & 27,357 & 134,047 \\
2005 & 15,054 & 33,217 & 125,083 \\
2006 & 21,778 & 44,334 & 110,703 \\
2007 & 23,999 & 35,310 & 101,587 \\
2008 & 28,906 & 38,526 & 100,831 \\
2009 & 30,469 & 50,764 & 90,922 \\
2010 & 67,853 & 78,333 & 103,275 \\
2011 & 72,776 & 91,586 & 84,664 \\
2012 & 81,696 & 103,303 & 71,937 \\
2013 & 145,684 & 130,583 & 63,346 \\
2014 & 131,166 & 128,955 & 114,612 \\
2015 & 136,353 & 120,890 & 103,102 \\
2016 & 173,999 & 139,588 & 92,398 \\
2017 & 218,524 & 146,685 & 114,332 \\
2018 & 375,903 & 119,238 & 118,641 \\
2019 & 292,046 & 161,024 & 118,129 \\
\hline
\end{tabular}

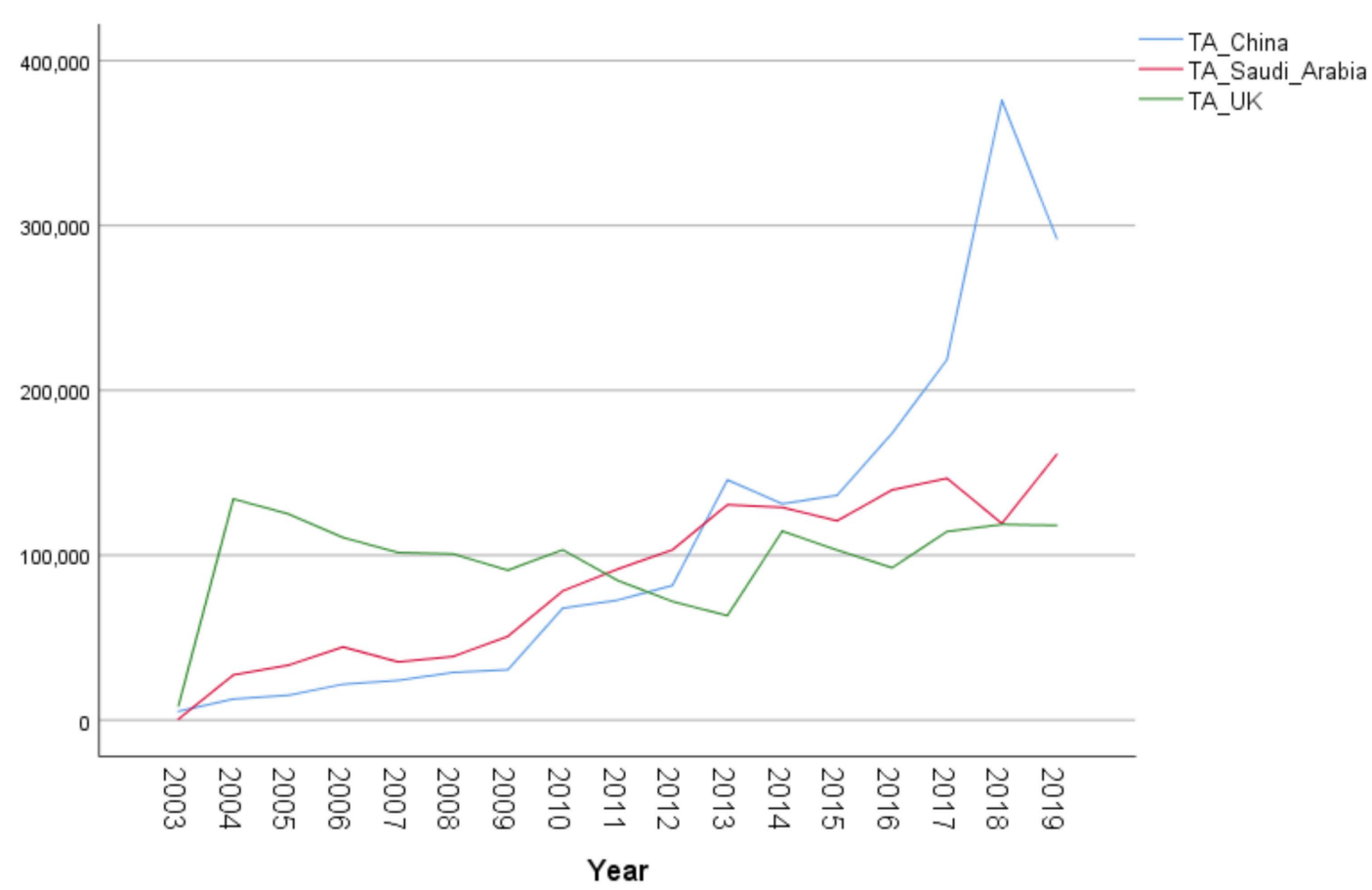

Figure 1. Tourist arrivals to Langkawi from China, Saudi Arabi, and the United Kingdom. Note: Y axis: Number of tourists; $X$ axis: Year.

The study analyzed yearly data from 2003-2019 on tourist arrivals from China to Langkawi, finding that the tourists had a healthy growth, from 5340 in 2003 to 292,046 in 2019, with the highest peak being 375,903 in 2018. The Holt linear model was used to forecast tourist arrivals from 2020-2022. In Table 2, the number of forecasted tourist arrivals from the top three source markets from 2020-2022 can be seen. With the present study, conducted in mid-2020, the forecasted results, especially for the 2020 data, is considered valid at that point in time of the data analysis. 
Table 2. Estimated number of tourist arrivals by country, 2020-2022.

\begin{tabular}{ccccc}
\hline Model & & $\mathbf{2 0 2 0}$ & $\mathbf{2 0 2 1}$ & $\mathbf{2 0 2 2}$ \\
\hline \multirow{3}{*}{ Estimate of Tourist Arrivals by Country } & China & 359,358 & 409,686 & 460,015 \\
& Saudi Arabia & 170,227 & 179,742 & 189,257 \\
& UK & 97,431 & 97,431 & 97,431 \\
\hline
\end{tabular}

Figure 2 displays the predicted values and actual observed values of Chinese tourist arrivals to Langkawi using the Holt linear model.

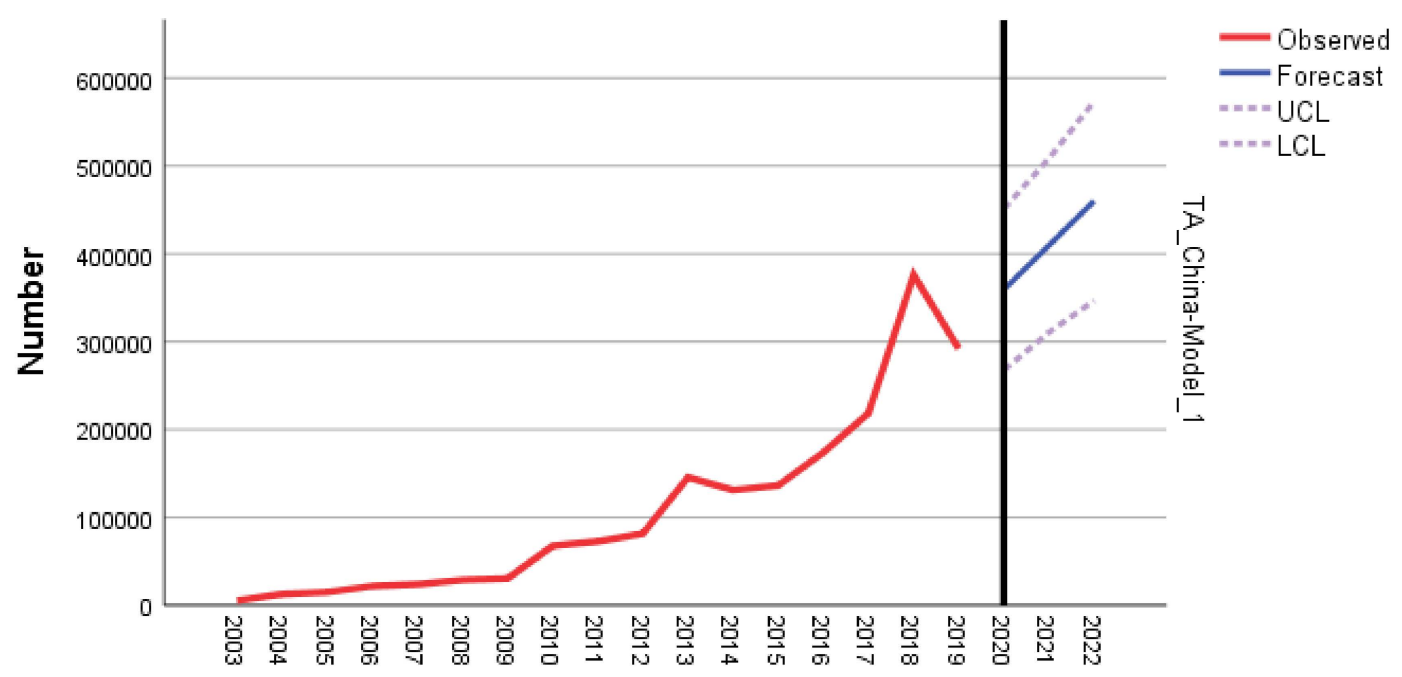

Date

Figure 2. Plot of predicted values and actual observed values of Chinese tourist arrivals to Langkawi, using the Holt linear model.

The study analyzed yearly data from 2003-2019 for Saudi Arabian tourist arrivals in Langkawi, finding that the number of tourists increased from just 565 in 2003 to the highest peak in 2019 at 161,024. The Holt linear model was also used to forecast tourist arrivals in 2020. In Figure 3, the number of forecasted tourist arrivals from Saudi Arabia can be seen.

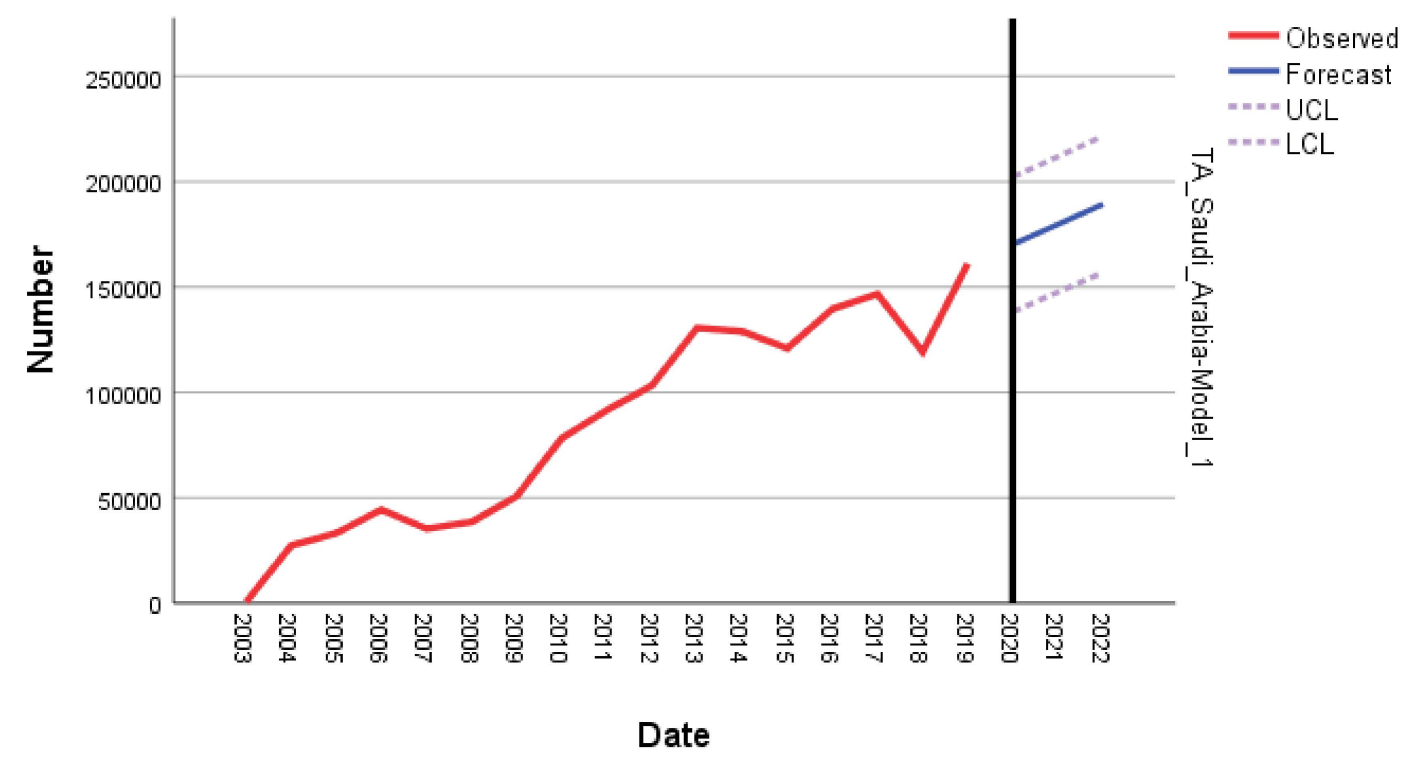

Figure 3. Plot of predicted values and actual observed values of Saudi Arabian tourist arrivals to Langkawi, using the Holt linear model. 
The study then analyzed yearly data from 2003-2019 for the United Kingdom's tourist arrivals in Langkawi, finding that the number of tourists increased from 8720 in 2003 to 118,129 in 2019, with the highest peak being in 2004 at 134,047. ARIMA $(0,0,0)$ was used to forecast the tourist arrivals in 2020. In Figure 4, the number of forecasted tourist arrivals from the United Kingdom can be seen.

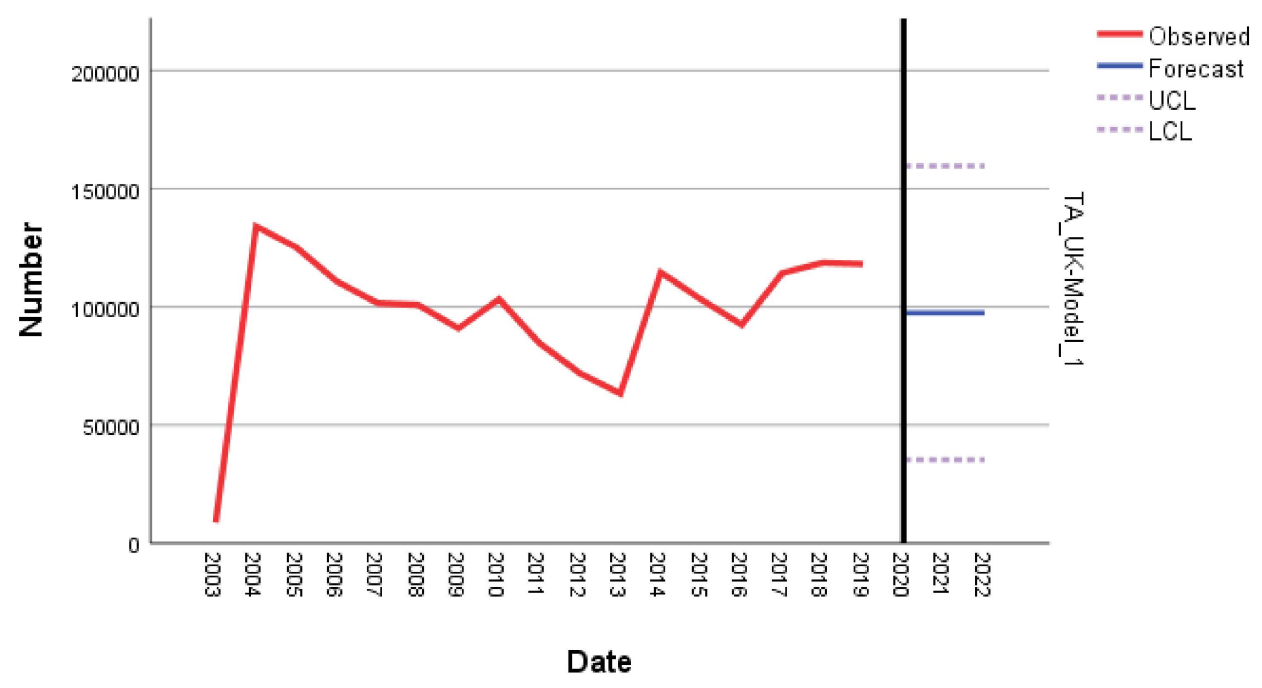

Figure 4. Plot of predicted values and actual observed values of the UK's tourist arrivals to Langkawi using ARIMA.

This study was conducted to analyze the data and conduct forecasting using the best fit time series model. To assess the forecasting performance of the data, RMSE, MAE, and MAPE were used with the smallest values taken, as shown in Table 3. The model accuracy was also highlighted by the R-square for each country's tourist arrivals. The $\mathrm{R}$-square for Chinese tourists to Langkawi is 0.848 , which means $84.8 \%$ of the forecasted tourist arrivals from China can be based on its yearly data. The R-square for Saudi Arabian tourists to Langkawi is 0.916 , which means $91.6 \%$ of the forecasted tourist arrivals from Saudi Arabia can be based on its yearly data. The R-square for the United Kingdom's tourists to Langkawi is 0.834 , which means $83.4 \%$ of the forecasted tourist arrivals from the United Kingdom can be based on its yearly data.

Table 3. MAE, RMSE, MAPE, R-square and stationary R-square values.

\begin{tabular}{cccccc}
\hline Tourist Arrivals & RMSE & MAE & MAPE & R-Square & $\begin{array}{c}\text { Stationary } \\
\text { R-Square }\end{array}$ \\
\hline China & $43,092.04$ & $23,683.69$ & 40.98 & 0.848 & 0.668 \\
Saudi Arabia & $15,015.39$ & $11,148.29$ & 86.03 & 0.916 & 0.662 \\
United Kingdom & $29,312.78$ & $20,305.85$ & 75.26 & 0.834 & 0.713 \\
\hline
\end{tabular}

Note: RMSE: root mean squared error; MAE: mean absolute error; MAPE: mean absolute percentage error.

According to the Holt's linear model for China and Saudi Arabia and the ARIMA $(0,0,0)$ model for the United Kingdom, the estimated forecasted tourist arrivals to Langkawi in 2020 are shown in Table 4, with a 95\% confidence level. Table 4 shows that tourist arrivals from China, Saudi Arabia, and the United Kingdom are estimated to increase to 359,358, 170,227, and 97,431, respectively, in 2020. 
Table 4. Forecasted tourist arrivals in 2020 (without COVID-19).

\begin{tabular}{cccc}
\hline Country & $\begin{array}{c}\text { Forecasted Tourist } \\
\text { Arrivals for 2020 }\end{array}$ & Upper Confidence Limit & Lower Confidence Limit \\
\hline China & 359,358 & 451,206 & 267,509 \\
Saudi Arabia & 170,227 & 202,232 & 138,222 \\
United Kingdom & 97,431 & 159,571 & 35,291 \\
\hline
\end{tabular}

However, the next part of this study will shed more light on the precision of these values, because if GDP has a significant relationship to the tourist arrivals of these countries, then a change in GDP will, in turn, impact the number of tourist arrivals from these countries.

To predict the effect of GDP on tourist arrivals from the top three source countries, linear regression was conducted. However, according to McGuirk, Driscoll, and Alwang [30], it is important to conduct a misspecification test before conducting the linear regression analysis. A significant misspecification suggests that the research has biased coefficients and error terms with a tendency towards biased parameter estimations. To ensure that the research conducted does not have any misspecification, heteroscedasticity analysis using a Breusch-Pagan test can be conducted. This will ensure that the regression model has homoscedasticity and therefore does not present any heteroscedasticity. The Breusch-Pagan test [31] was conducted to determine whether heteroscedasticity is present in this research model or not. The test used null and alternative hypotheses:

Null Hypothesis. Homoscedasticity is present in the regression model (the residuals are distributed with equal variance);

Alternative Hypothesis. Heteroscedasticity is present (the residuals are not distributed with equal variance).

To conduct the Breusch-Pagan test, the following steps were taken:

1. Linear regression was conducted between dependent and independent variables;

2. Unstandardized predicted and residual values were recorded;

3. Unstandardized residual value was squared to conduct the Breusch-Pagan test;

4. Linear regression was again performed using unstandardized residual values as the dependent variable (separately for China, Saudi Arabia, and the UK) and independent variable (separately for the GDP of China, the GDP of Saudi Arabia, and the GDP of the UK);

5. The output of significance ( $p$-value) was analyzed to see whether heteroscedasticity is present in the regression models or not.

Table 5 shows that the $p$-value of the test is 0.555 (>0.05). Therefore, the null hypothesis of the data fails to reject that homoscedasticity is present in the regression model. This means the data for this linear regression model is free from misspecification.

Table 5. Heteroscedasticity analysis output between Chinese tourist arrivals to Langkawi and the annual GDP growth of China.

\begin{tabular}{llllll}
\hline Model & Sum of Squares & Df & Mean Square & F & Sig \\
\hline Regression & $24,957,257,748,255,080,000.000$ & 1 & $24,957,257,748,255,080,000.000$ & 0.365 & 0.555 \\
Residual & $1,024,582,755,248,987,200,000.000$ & 15 & $68,305,517,016,599,140,000.000$ & & \\
Total & $1,049,540,012,997,242,300,000.000$ & 16 & & &
\end{tabular}

Dependent variable: unstandardized residual square of Chinese tourist arrivals to Langkawi; Independent variable: annual GDP growth of China.

Table 6, below, shows that the $p$-value of the test is $0.84(>0.05)$. Therefore, the null hypothesis of the data fails to reject that homoscedasticity is present in the regression model. This means the data for this linear regression model is free from misspecification. 
Table 6. Heteroscedasticity analysis output between Saudi Arabian tourist arrivals to Langkawi and the annual GDP growth of Saudi Arabia.

\begin{tabular}{llllll}
\hline Model & Sum of Squares & Df & Mean Square & F & Sig \\
\hline Regression & $6,300,408,641,439,998,000.000$ & 1 & $6,300,408,641,439,998,000.000$ & 3.418 & 0.84 \\
Residual & $27,648,017,967,623,705,000.000$ & 15 & $1,843,201,197,841,580,290.000$ & & \\
Total & $33,948,426,609,063,703,000.000$ & 16 & & & \\
Dependent variable: unstandardized residual square of Saudi Arabian Tourist Arrivals to Langkawi; Independent \\
variable: annual GDP growth of Saudi Arabia.
\end{tabular}

Table 7 , below, shows that the $p$-value of the test is $0.246(>0.05)$. Therefore, the null hypothesis of the data fails to reject that homoscedasticity is present in the regression model. This means the data for this linear regression model is free from misspecification.

Table 7. Heteroscedasticity analysis output between the UK's tourist arrivals to Langkawi and the annual GDP growth of the UK.

\begin{tabular}{cccccc}
\hline Model & Sum of Squares & Df & Mean Square & F & Sig \\
\hline Regression & $4,736,697,307,299,766,300.000$ & 1 & $4,736,697,307,299,766,300.000$ & 1.458 & 0.246 \\
Residual & $48,731,783,392,845,780,000.000$ & 15 & $3,248,785,559,523,052,000.000$ & & \\
Total & $53,468,480,700,145,550,000.000$ & 16 & & &
\end{tabular}

Dependent variable: unstandardized residual square of the UK's tourist arrivals to Langkawi; independent variable: annual GDP growth of the UK.

Following the results of the misspecification test, this research conducted a linear regression analysis to establish the relationship between tourist arrivals from China, Saudi Arabia, and the United Kingdom and their annual GDP growth. Tables 8-10, below, show the significance levels and standard betas of each country. According to the result output, China's annual GDP growth $(\beta=0.757, p<0.05)$ and Saudi Arabia's annual GDP growth ( $\beta=0.500, p<0.05$ ) have a significant positive relationship to the tourist arrivals from these countries to Langkawi. However, the United Kingdom's annual GDP growth ( $\beta=0.030$, $p>0.05$ ) does not have a significant relationship to the tourist arrivals from the United Kingdom to Langkawi. This means that GDP growth can impact tourist arrivals from China and Saudi Arabia but it will not have any significant effect on tourist arrivals from the United Kingdom.

A $\beta$ coefficient value indicates the contribution of a variable in predicting the dependent variable. A significant $\beta$ coefficient indicates a statistically significant relationship between the variables. The coefficient ranges from $0-1$; the higher the value of the beta, the stronger the contribution of the variable to the dependent variables [32]. In the present study, significant $\beta$ coefficient values for China and Saudi Arabia indicate that the annual GDP growth of the two countries have a significant positive relationship to the tourist arrival trend to Langkawi.

Table 8. Linear regression analysis output between Chinese tourist arrivals to Langkawi and the annual GDP growth of China.

\begin{tabular}{cccc}
\hline Independent Variable & $\begin{array}{c}\text { Standard } \\
\text { Beta Coefficient }\end{array}$ & $t$ & $\begin{array}{c}\text { Significance: } \\
p \text {-Value }\end{array}$ \\
\hline Annual GDP Growth of China & 0.757 & 4.489 & 0.000 \\
\hline $\mathrm{R}=0.757$; R-square $=0.573$; Adjusted R-square $=0.545 ;$ F-statistic $=20.158$.
\end{tabular}

Equation: Tourist arrivals from China $=0.757$ annual GDP growth of China 
Table 9. Linear regression analysis output between Saudi Arabian tourist arrivals to Langkawi and the annual GDP growth of Saudi Arabia.

\begin{tabular}{cccc}
\hline Independent Variable & $\begin{array}{c}\text { Standard } \\
\text { Beta Coefficient }\end{array}$ & $\boldsymbol{t}$ & $\begin{array}{c}\text { Significance: } \\
\boldsymbol{p} \text {-Value }\end{array}$ \\
\hline Annual GDP Growth of Saudi Arabia & 0.500 & 2.237 & 0.041 \\
\hline $\mathrm{R}=0.500 ; \mathrm{R}$-square $=0.250$; Adjusted R-square $=0.200 ;$ F-statistic $=5.005$. &
\end{tabular}

Equation: Tourist arrivals from Saudi Arabia $=0.500$ annual GDP growth of Saudi Arabia

Table 10. Linear regression analysis output between the United Kingdom's tourist arrivals to Langkawi and the annual GDP growth of the United Kingdom.

\begin{tabular}{cccc}
\hline Independent Variable & $\begin{array}{c}\text { Standard } \\
\text { Beta Coefficient }\end{array}$ & $\boldsymbol{t}$ & $\begin{array}{c}\text { Significance: } \\
\boldsymbol{p} \text {-Value }\end{array}$ \\
\hline Annual GDP Growth of the United Kingdom & 0.030 & 0.115 & 0.910 \\
\hline $\mathrm{R}=0.030 ; \mathrm{R}$-Square $=0.001$; Adjusted R-square $=-0.066$; F-statistic $=0.13$. & &
\end{tabular}

Equation: Tourist arrivals from United Kingdom $=0.030$ annual GDP growth of the United Kingdom

\section{Discussion}

This study is the first study to forecast on tourist arrival trends to Langkawi by focusing on Langkawi's top source markets, namely, China, Saudi Arabia, and the UK, before delving further to explore whether changes in the annual GDP growth of the said countries would influence the trend.

Using an expert modeler, the present study has predicted the number of tourist arrivals from China, Saudi Arabia, and the UK to Langkawi from 2020-2022. Using the Holt linear model, the present study forecasted the number of tourist arrivals from China to Langkawi at 359,358 in 2020, 409,686 in 2021, and 460,015 in 2022. The same model was used to forecast Saudi Arabian tourist arrivals. The results indicated a steady increase of tourist arrival trends from the country from 170,227 in 2020 to 179,742 in 2021 and 189,257 in 2022. The ARIMA model was then used to forecast the UK's tourist arrivals. The result showed a static trend, which remains at 97,431 from 2020-2022. The R-square values of 0.848 for China, 0.916 for Saudi Arabia, and 0.834 for the UK indicated a good forecasting performance for all the three top source markets to Langkawi.

Generally, we can conclude that, without COVID-19, Langkawi would have seen an increasing trend in tourist arrivals, by $14 \%$ in 2021 and $12.3 \%$ in 2022, from China. Tourists from Saudi Arabia will increase by $5.6 \%$ in 2021 and 5.3\% in 2022. However, no changes in tourist arrival trend can be discerned for tourists from the United Kingdom for the next two years.

To predict the impact of GDP on tourist arrivals, the present research conducted a linear regression analysis to establish the relationship between tourist arrivals in China, Saudi Arabia, and the United Kingdom to their annual GDP Growth. The results further showed that changes in GDP will impact tourist arrivals from China and Saudi Arabia but will not have any significant effect on tourist arrivals from the United Kingdom. This finding, in particular, has an important implication to the tourism development of Langkawi in the post-pandemic era. With the GDP of China and Saudi Arabia playing a significant role in the inbound tourist arrivals of their citizens to Langkawi, it is predicted that the number of tourists from the two countries will be negatively affected, especially during the post-pandemic era. In other words, the GDP is predicted to be more significant upon the Chinese and Saudi Arabian markets, as compared to the UK market, which has been on a static trend. It is believed that lower GDPs during the post-pandemic era will cause a negative influence on the total number of inbound tourist arrivals from China and 
Saudi Arabia to Langkawi. However, it will not register any adverse impact on tourist arrivals from the United Kingdom.

This finding has a strong implication on the post-recovery period of the pandemic. With data of the linear regression analysis showing the strong influence of annual GDP growth on tourist arrivals to Langkawi, especially for countries like China and Saudi Arabia, it is expected that the post-COVID-19 tourism recovery period will be longer for these two countries, compared to the UK. In other words, for Langkawi, the UK market will recover faster and is more resilient than the other two countries due to a lesser reliance on GDP for tourism growth. Evidence of the dependent structure in GDP and tourism growth rates have been documented in many studies [33,34].

GDP indicates the size of a country's economy calculated by the total dollar value of all goods and services produced by an economy over a specific time period. GDP growth implies the health of a country's economy. Compared to China and Saudi Arabia, the UK is less dependent on tourism, which contributes about 9.3\% to its GDP, while China is $11.3 \%$ and Saudi Arabia is 9.5\% [35]. With COVID-19 ravaging the travel and tourism industries in many countries, severe economic impacts can be observed, especially among the countries most dependent on the travel and tourism industries for their economic growth, such as China and Saudi Arabia. However, the opposite is forecasted for the UK, due to its lower reliance on the tourism industry for its overall GDP growth. In other words, a speedy rate of recovery in the number of tourists from the UK to Langkawi is forecasted once international travel restrictions are lifted, as the world eases into the post-pandemic period.

\section{Conclusions}

The present forecasting models deliver the predicted number of tourist arrivals from 2020-2022, which was plotted without taking into account the adverse impact wreaked by the COVID-19 pandemic. Generally, we can conclude that without COVID-19, Langkawi would have recorded a steady trend in tourist arrivals from China and Saudi Arabia. However, no changes in tourist arrival trends will be observed for tourists from the United Kingdom for the next two years. The impact of COVID-19 is predicted to be more significant for both the Chinese and Saudi Arabian markets, in sharp contrast to the UK market.

\subsection{Implications for Society}

This study is timely, as we are in a transition period towards post-pandemic recovery. Recent announcements on mass vaccine rollouts in many countries, and the COVID-19 national vaccination plan for all Malaysians, have provided some solace, spurring hope that the pandemic's end is in sight. As we advance towards the post-pandemic phase, the results of this study will help countries, including Malaysia, to better predict the impact of GDP upon the tourism industry to establish appropriate tourism policies in order to be better-prepared in the future. Findings can assist both governmental, non-governmental, and private agencies in the development of bounce-forward strategies, rather than the bounce-back notions that have often been practiced in the past. The bounce-forward strategies would involve the complete realization that the risk of COVID-19 will continue to be part of our lives. Hence, this requires a total re-evaluation of the current social systems, social practices, business models, and systems of operation [36].

\subsection{Implications for Industry}

Specifically for Langkawi, this study identified the impacts of GDP on inbound international tourists from its top source markets, and found evidence of the impact on different source countries. To make up for the loss due to the significant reduction of inbound international tourists, Langkawi can focus on enhancing domestic arrivals. The future plan should focus on expanding tourist attractions to wider geographical areas, which is achievable by promoting recreational, underwater, and nautical activities, such as sailing and fishing, to reduce the concentration of tourists at any one time in a 
particular geographical area. By allaying lingering fears among tourists, it is necessary to develop more effective management protocols before and during a crisis to ensure the safety and health of all, by ensuring that standard operating procedures (SOPs) are adhered to. Advanced technologies, such as artificial intelligence (AI), and social distancing measurements and warning systems should be considered to detect density of and distance among people in public areas such as beaches, shopping malls, and airports [37].

The findings of the present study would benefit many tourism stakeholders, especially the Langkawi Development Authority, which is the main government agency responsible for the tourism development and growth of the island. Being the least tourism-dependent country, the UK will quickly recover from the impact of the pandemic. The country is also projected to be the fastest-growing G7 country in 2022, surpassing the US, Japan, Germany, France, Italy, and Canada [38]. The UK's GDP is expected to increase by $6.8 \%$ in 2021, compared to Saudi Arabia at 2.8\%. China, despite showing good a GDP forecast at $8 \%$ for the year 2021 [39], is imposing a longer halt to its outbound travel for the next 1-2 years, due to various restrictions imposed by the government [40]. With findings describing the minimal impact of GDP upon the UK's economy, a more strategized campaign should be targeted at and planned for this specific market, especially during the post-pandemic era.

\subsection{Limitations of the Study}

Despite the valuable findings, it is also important to address some limitations of the present study. Firstly, it is limited by the available annual dataset on tourist arrivals to Langkawi from three source countries, namely, China, Saudi Arabia, and the UK. Monthly and quarterly data are only available for the overall international tourist arrivals. The forecasting of international tourist arrivals has been conducted by many previous researchers. To add value, the present study forecasts tourist arrivals from the top three source countries for Langkawi. However, only yearly data is available for this, due to different data-recording systems used by the agencies responsible. For Langkawi, the systematic recording of tourist arrival data only began in 2003 , leaving us with data points for only 17 years until 2019, which may limit its predictive power. While it is well-understood that power increases along with the number of data points, "there are no specific limits regarding the number of data points, as the power depends on various other factors, including distribution of data points, variability within the data, strength of effect, and the presence of confounding effects such as seasonality" (p. 350). Studies with few time points, however, should be interpreted with care [41].

A second limitation pertains to the use of univariate time series models in generating the prediction model with data on GDP growth that was analyzed separately using linear regression analysis. Future research should consider utilizing multivariate analysis to obtain more a precise understanding of tourist arrival trends for Langkawi from its main source markets. With the pandemic impacting the tourism industry, it is also important to incorporate other economic factors, such as the currency rate, or sustainability factors, such as environmental pollution, into the forecasting model. The possible spurious results and degrees of freedom should be further tested in the next study [8].

Notwithstanding these limitations, the present study is the first study to specifically forecast tourist arrivals for the top three source countries to Langkawi. Using the annual gross domestic product (GDP) growth of the said three countries, the present study is also novel and timely, as it empirically measures the effect of GDP upon the tourist arrivals trend, using GDP growth as the basis of analysis in order to reflect on the findings in the context of the post-pandemic era.

Author Contributions: Conceptualization, methodology, writing —original draft preparation, writingreview and editing, and funding acquisition was completed by H.M.; software, data curation, data validation, and data analysis was completed by F.A.; data acquisition and data validation was completed by W.W.Z.; final editing and formatting was completed by A.M.E. All authors have read and agreed to the published version of the manuscript. 
Funding: This work was supported by a Universiti Sains Malaysia Bridging Grant Scheme, with Project Number 304. PCOMM. 6316392.

Data Availability Statement: The data used in the study are public data available from Tourism Malaysia, http:/ / mytourismdata.tourism.gov.my/, (accessed on 17 February 2021).

Acknowledgments: We would like to record our appreciation to Universiti Sains Malaysia for providing the financial support to the study.

Conflicts of Interest: The authors declare no conflict of interest. The funder had no role in the design of the study; in the collection, analyses, or interpretation of data; or in the writing of the manuscript.

\section{References}

1. Malaysia Tourism Statistics in Brief. Available online: https://www.tourism.gov.my/statistics (accessed on 13 October 2021).

2. Visit Malaysia 2020 Targets to Bring in RM100b in Tourist Receipts by NST Business. New Straits Times, 7 March 2019. Available online: https:/ / www.nst.com.my / business / 2019/03/466912/visit-malaysia-2020-targets-bring-rm100b-tourist-receipts(accessed on 13 October 2021).

3. Langkawi Tourism Blueprint 2016-2020. Available online: https://www.lada.gov.my/en/langkawi-tourism-blueprint/ (accessed on 13 March 2021).

4. Fan, T.; Pu, B.; Powpaka, S.; Hao, L. The Impact of Disaster of a National Airline on the Nation's Tourism: An Empirical Investigation. Sustainability 2019, 11, 1233. [CrossRef]

5. High Hope for Local Tourism Section. Available online: www.nst.com.my/news/nation/2020/12/647989/high-hopes-localtourism-sector (accessed on 17 February 2021).

6. Gross Domestic Product: An Economy's All. 24 February 2020. Available online: https://www.imf.org/external/pubs/ft/ fandd/basics/gdp.htm (accessed on 13 October 2021).

7. Pedak, M. The Effect of Tourism on GDP. Bachelor's Thesis, Jonkoping University, Jönköping, Sweden, 2018.

8. Gričar, S.; Bojnec, Š.; Karadžić, V.; Backović Vulić, T. Tourism-led economic growth in Montenegro and Slovenia. Econ. Res.-Ekon. Istraživanja 2021. [CrossRef]

9. Croes, R.R.; Vanegas, M. An Econometric Study of Tourist Arrivals in Aruba and Its Implications. Tour. Manag. 2005, 26, 879-890. [CrossRef]

10. Luzzi, G.; Flückiger, Y. An Econometric Estimation of the Demand for Tourism: The Case of Switzerland. Pac. Econ. Rev. 2003, 8, 289-303. [CrossRef]

11. Ghani, G.M. Tourist Arrivals to Malaysia from Muslim Countries. Tour. Manag. Perspect. 2016, 20, 1-9. [CrossRef]

12. Policy Support and Vaccines Expected to Lift Activity. World Economic Outlook, January 2021. Available online: https://www.imf. org/en/Publications/WEO/Issues/2021/01/26/2021-world-economic-outlook-update(accessed on 13 October 2021).

13. Gross Domestic Product (GDP) by State. 2020. Available online: www.dosm.gov.my/v1/index.php?r=column/ctwoByCat\&paent_id=99\&menu_id=TE5CRUZCblh4ZTZMODZIbmk2aWRRQT09 (accessed on 13 October 2021).

14. The World Bank. GDP Growth. Available online: https://data.worldbank.org/indicator/NY.GDP.MKTP.KD.ZG (accessed on 13 October 2021).

15. UNWTO. Available online: www.unwto.org (accessed on 12 January 2021).

16. COVID-19: Malaysians Tourism Industry Hit RM45 Billion Losses. Available online: www.nst.com.my/news/nation/2020/06/ 604012/covid-19-malaysias-tourism-industry-hit-rm45-billion-losses (accessed on 19 March 2021).

17. Year 2020 Langkawi Tourism Income Set RM9 Billion. Available online: http:/ /www.mplbp.gov.my/en/mplbp/media-centre/ news/year-2020-langkawis-tourism-income-set-rm9-billion (accessed on 17 February 2021).

18. Gričar, S.; Šugar, V.; Bojnec, Š. The Missing Link between Wages and Labour Productivity in Tourism: Evidence from Croatia and Slovenia. Econ. Res.-Ekon. Istraživanja 2020, 34, 732-753. [CrossRef]

19. Mustafa, H.; Omar, B.; Mukhiar, S.N.S. Measuring Destination Competitiveness: An Importance-Performance Analysis (IPA) of Six Top Island Destinations in South East Asia. Asia Pac. J. Tour. Res. 2020, 25, 223-243. [CrossRef]

20. Sheldon, P.J.; Var, T. Tourism Forecasting: A Review of Empirical Research. J. Forecast. 1985, 4, 183-195. [CrossRef]

21. Chuah, S.C. Forecasting Tourist Arrivals to Malaysia. Master's Thesis, Universiti Putra Malaysia, Serdang, Malaysia, 2001.

22. Shitan, M. Time Series Modelling of Tourist Arrivals to Malaysia; InterStat: Durban, South Africa, 2008; pp. 1-12. ISSN 1941-689X.

23. Yahya, A.E.; Samsudin, R.; Ilman, A.S. A Genetic Algorithm-Based Grey Model Combined with Fourier Series for Forecasting Tourism Arrivals in Langkawi Island Malaysia. Emerging Trends in Intelligent Computing and Informatics. In Proceedings of the IRICT 2019. Advances in Intelligent Systems and Computing, Johor, Malaysia, 22-23 September 2019; Saeed, F., Mohammed, F., Gazem, N., Eds.; Springer: Berlin/Heidelberg, Germany, 2020; Volume 1073. [CrossRef]

24. Mansor, K.A.; Ishak, W.I. Forecasting Tourist Arrival to Langkawi Island Malaysia. Cross-Cult Manag. 2015, XVII, 1. Available online: https://seaopenresearch.eu/Journals/articles/CMJ2015_I1_9.pdf (accessed on 13 October 2021).

25. Fauzi, N.F.; Ahmadi, N.S.; Shafii, N.H.; Ab Halim, H.Z. A Comparison Study on Fuzzy Time Series and Holt-Winter Model in Forecasting Tourist Arrival in Langkawi, Kedah. J. Comput. Res. Innov. 2020, 5, 1. Available online: https://crinn.conferencehunter. com/index.php/jcrinn/article/view/138 (accessed on 13 October 2021). [CrossRef] 
26. Azmi, N.İ.L.M. Parameters Estimation Of Holt-Winter Smoothing Method Using Genetic Algorithm. Unpublished Dissertation. 2013. Available online: http:/ / eprints.utm.my/id/eprint/32356/1/NurIntanLiyanaMohdAzmiMFS2013.pdf (accessed on 13 October 2021)

27. Karadzic, V.; Pejovic, B. Inflation Forecasting in the Western Balkans and EU: A Comparison of Holt-Winters, ARIMA and NNAR Models. Amfiteatru Econ. 2021, 23, 517-532. [CrossRef]

28. Gligorijevic, Z.; Stefanovic, V. Tourism as a Socio-Economic Phenomenon: Conceptual and Time Coverage. Econ. Themes 2013, 3, 273-287.

29. Understanding Tourism Basic Glossary. Available online: http://media.unwto.org/en/content/understanding-tourism-basicglossary (accessed on 17 February 2021).

30. McGuirk, A.M.; Driscoll, P.; Alwang, J. Misspecification Testing: A Comprehensive Approach. Am. J. Agric. Econ. 1993, 75, 1044-1055. [CrossRef]

31. Breusch, T.S.; Pagan, A.R. A Simple Test for Heteroscedasticity and Random Coefficient Variation. Econometrica 1979, 47, 1287-1294. [CrossRef]

32. Pallant, J. SPSS Survival Manual. A Step by Step Guide to Data Analysis Using SPSS, 4th ed.; Allen \& Unwin: Sydney, Australia, 2011.

33. Pérez-Rodríguez, J.V.; Ledesma-Rodríguez, F.; Santana-Gallego, M. Testing dependence between GDP and tourism's growth rates. Tour Manag. 2015, 48, 268-282. [CrossRef]

34. Ming-Hsiang, C. The economy, tourism growth and corporate performance in the Taiwanese hotel industry. Tour Manag. 2010, 31, 665-675. [CrossRef]

35. World Travel \& Tourism Council. 2019. Available online: https://wttc.org/Research/Economic-Impact (accessed on 12 February 2021).

36. Manyena, B.; O’Brien, G.; O’Keefe, P.; Rose, J. Disaster resilience: A bounce back or bounce forward ability? Local Environ. Int. J. Justice Sustain. 2011, 16, 417-424. [CrossRef]

37. Artificial Intelligence Backed Support for Social Distancing Control. Available online: www.dailysabah.com/business/tech/ artificial-intelligence-backed-support-for-social-distancing-control (accessed on 17 February 2021).

38. Western Economies Recovering Faster than Expected from COVID, Says IMF. The Guardian, 2021. Available online: https://www theguardian.com/business/2021/apr/06/western-economies-covid-imf-growth-forecast-us-uk(accessed on 17 October 2021).

39. Real GDP Growth, Intarnational Monetary Fund. Available online: https://www.imf.org/external/datamapper/NGDP_RPCH@ WEO/OEMDC/ADVEC/WEOWORLD (accessed on 17 October 2021).

40. Chen, G.; Phillips, M.; Saxon, S.; Yu, J. China's Uneven Travel Recovery: Long Road to International Travel Furthers Domestic Opportunities. 2021. Available online: https:/ / www.mckinsey.com/industries/travel-logistics-and-infrastructure/our-insights/ chinas-uneven-travel-recovery-long-road-to-international-travel-furthers-domestic-opportunities (accessed on 17 October 2021).

41. Zhang, F.; Wagner, A.K.; Ross-Degnan, D. Simulation-based Power Calculation for Designing Interrupted Time Series Analyses of Health Policy Interventions. J. Clin. Epidemiol. 2011, 64, 1252-1261. [CrossRef] [PubMed] 